\title{
Tata Kelola Stakeholder dalam Meningkatkan Mutu Pendidikan Pada Madrasah Tsanawiyah
}

\author{
Ihsan Muhadi $\left.{ }^{*}\right)$, Giyoto ${ }^{2)}$, Lilik Untari ${ }^{3)}$ \\ 1,2,3 Institut Agama Islam Negeri (IAIN) Surakarta \\ *Email korespondensi: ihsanmuhadi@gmail.com
}

\begin{abstract}
This study aims to determine stakeholder governance in improving the quality of education at Madrasah Tsanawiyah (MTs) Negeri 1 Sukoharjo. This governance includes the management of teaching staff and education personnel in improving the quality of secondary education at MTs Negeri 1 Sukoharjo, student management in improving the quality of secondary education at MTs Negeri 1 Sukoharjo, governance of partner communities and graduate users in improving the quality of secondary education at MTs Negeri 1 Sukoharjo. The methodology in this study uses a qualitative approach. Data collection techniques in this study include observation, in-depth interviews, FGD (Focus Group Discussion), and document review. Data analysis in this study was carried out in 4 (four) steps, namely: 1) performing data management, 2) writing memos on the edge of field notes or transcripts to assist database exploration, 3) delineation, classification, and interpretation, and 4) visualization and representation findings. The results showed that the governance of stakeholders in improving the quality of education at Madrasah Tsanawiyah (MTs) Negeri 1 Sukoharjo which includes the management of teachers and education personnel, student governance, and how madrasahs manage the role of stakeholders in improving the quality of secondary education at Madrasah Tsanawiyah (MTs) Negeri 1 Sukoharjo is done very well so that the quality of education at Madrasah Tsanawiyah (MTs) Negeri 1 Sukoharjo is very good.
\end{abstract}

Keywords: governance of stakeholders, quality of education, Madrasah Tsanawiyah

Saran sitasi: Muhadi, I,. Giyoto., \& Untari, L. (2021). Tata Kelola Stakeholder Dalam Meningkatkan Mutu Pendidikan Pada Madrasah Tsanawiyah. Jurnal Ilmiah Ekonomi Islam, 7(01), 256-265. doi:http://dx.doi.org/10.29040/jiei.v7i1.2209

DOI: http://dx.doi.org/10.29040/jiei.v7i1.2209

\section{PENDAHULUAN}

Madrasah adalah lembaga pendidikan Islam yang memadukan sistem pendidikan pondok pesantren tradisional dan pendidikan sekolah modern. Keberadaan madrasah merupakan wujud dari kesadaran umat Islam guna menyiapkan generasi masa depan yang lebih baik. Madrasah diharapkan dapat mendidik siswanya agar memiliki kemampuan dalam bidang sains dan teknologi, tetapi tetap memiliki identitas keislaman. Pendidikan di madrasah diharapkan mampu meningkatkan mutu pendidikan bagi masyarakat luas dalam rangka meningkatkan mutu sumber daya manusia Indonesia.

Pendidikan di Indonesia secara umum, tentunya termasuk pendidikan di madrasah, sampai hari ini masih mengalami banyak permasalahan. Salah satu permasalahan pendidikan yang dihadapi rendahnya mutu pada setiap jenjang pendidikan. Rendahnya mutu pendidikan tersebut dapat dilihat dari hasil riset internasional yang selalu menempatkan pendidikan Indonesia dalam posisi 'juru kunci'. Hasil studi The Third International Mathematics And Science Sudy Repeat (TIMSSS-R 1999) yang dilaksanakan pada 38 negara dari lima benua yaitu Asia, Australia, Afrika, Amerika, dan Eropa, menempatkan peserta didik SLTP/MTS dari Indonesia pada urutan 32 dan 34 untuk skor tres matematika dan IPA. Indikator lainnya menunjukkan bahwa berdasarkan pada Human Development Index (HDI), Indonesia berada pada urutan yangke 102 dari 164 negara dan Indonesia masih berada di bawah Vietnam (Maryono, 2018).

Berdasarkan data yang dikutip dari Kantor Kementerian Agama Kabupaten Sukoharjo, jumlah Madrasah Tsanawiyah (MTs) di Kabupaten Sukoharjo hingga tahun 2020 sebanyak 18 (delapan belas) Madrasah Tsanawiyah, terdiri dari 3 (tiga) MTs 
Negeri dan 15 (lima belas) MTs Swasta. Dari 18 (delapan belas) Madrasah Tsanawiyah tersebut terbagi menjadi 3 (tiga) kriteria, yaitu; Madrasah Tsanawiyah (MTs) yang menyelenggarakan kegiatan belajar mengajar terintegrasi langsung dengan penyelenggaraan pondok pesantren; Madrasah Tsanawiyah (MTs) yang menyelenggarakan kegiatan belajar mengajar dengan penambahan program khusus; dan Madrasah Tsanawiyah (MTs) reguler yang menyelenggarakan kegiatan belajar mengajar seperti sekolah umum tetapi bercirikan keagamaan.

Karakteristik Madrasah Tsanawiyah (MTs) pondok pesantren materi pelajaran yang diajarkan adalah pelajaran agama yang bersumber dari kitabkitab klasik, siswa tinggal di asrama, dan kurikulum madrasah dikembangkan oleh pondok sendiri ditambah dengan kurikulum pemerintah yang diintegrasikan dengan materi pelajaran agama. Kelebihannya adalah madrasah lebih kental dengan karakter keIslamannya dan penguasaan bahasa Arab yang lebih menonjol.

Karakteristik Madrasah Tsanawiyah (MTs) program khusus memiliki struktur kurikulum yang lebih banyak dengan penguatan kompetensi pada mata pelajaran nasional, jam belajar lebih banyak dari reguler, siswa yang diterima melalui seleksi, fasilitas untuk kegiatan belajar mengajar lebih memadai dan modern, dan kegiatan pengembangan diri yang lebih banyak, lebih variatif, sesuai dengan bakat dan minat siswa. Kelebihannya adalah lebih mengembangkan sumber daya yang ada untuk menuju terbentuknya manusia seutuhnya (insan kamil) yang sesuai dengan norma agama.

Karakteristik Madrasah Tsanawiyah (MTs) reguler memiliki pola pembelajaran in between, yaitu pelajaran umum ditambah dengan pelajaran agama. Madrasah reguler memberikan pelayanan pendidikan kepada setiap masyarakat tanpa terkecuali. Kelebihannya adalah biaya yang lebih murah, sebanding dengan fasilitasnya, tidak hanya belajar mata pelajaran umum saja dan punya banyak kegiatan keagamaan.

Berdasarkan data kependidikan yang dikeluarkan oleh Kantor Kementerian Agama Kabupaten Sukoharjo, jumlah pendaftar pada Madrasah Tsanawiyah menunjukkan adanya kepercayaan masyarakat untuk menyekolahkan anakanya di Lembaga Madrasah Tsanawiyah cukup tinggi, hal ini dibuktkan dalam tiga tahun terakhir jumlah pendaftar rata-rata mengalami peningkatan pada setiap tahunnya. Tahun ajaran 2017/2018 jumlah siswa baru 2.613, tahun ajaran 2019/2020 jumlah siswa baru 2.937 dan tahun ajaran 2020/2021 jumlah siswa baru 3.366 siswa

Peningkatan minat masyarakat untuk menyekolahkan anaknya di Madrasah Tsanwiyah menjadi salah satu indikator masih adanya kepercayaan masyarakat terhadap Madrasah Tsanawiyah. Meskipun secara umum dapat dinyatakan bahwa penyelenggaraan pendidikan di Madrasah Tsanawiyah masih ditemukannya berbagai kendala yang menghambat peningkatan mutu madrasah. Hal tersebut dapat diketahui dengan melihat perolehan nilai Ujian Nasional (UN), dimana para calon peserta didik madrasah relatif lebih rendah jika dibandingkan dengan mereka yang masuk ke sekolah umum. Kemudian terbatasnya tenaga pendidik (guru) khususnya yang memiliki kualifikasi pendidikan yang sesuai dan minimnya dukungan dana dari pemerintah dan masyarakat berakibat pada terhambatnya peningkatan mutu madrasah.

Konsep pendidikan yang bermutu adalah pendidikan yang mampu menjawab berbagai tantangan dan permasalahan yang akan dihadapi sekarang dan masa yang akan datang. Mutu pendidikan adalah kemampuan lembaga dan sistem pendidikan dalam memberdayakan sumber-sumber pendidikan untuk meningkatkan mutu yang sesuai dengan harapan atau tujuan pendidikan melalui proses pendidikan yang efektif. Karakteristik pendidikan yang bermutu adalah pendidikan yang dapat menghasilkan lulusan yang bermutu, yaitu lulusan yang memiliki prestasi akademik dan non-akademik yang mampu menjadi pelopor pembaruan dan perubahan sehingga mampu menjawab berbagai tantangan dan permasalahan yang dihadapinya, baik di masa sekarang atau di masa yang akan datang (Sukmadinata, dkk., 2006).

Upaya perbaikan mutu pendidikan di madrasah selama ini yang sering disorot dan diperhatikan adalah melakukan perubahan dari segi program (kurikulum) tanpa dibarengi dengan perbaikan manajemen dan pengelolaan pendidikan. Program (kurikulum) berubah, namun orang yang akan menjalankannya serta manajemen terhadap implementasi program (kurikulum) tidak tertata dan terkelola dengan baik. Akhirnya program kurikulum yang ditetapkan tidak mampu diimplementasikan secara maksimal sesuai dengan yang diharapkan. Hal ini karena tidak diiringi 
dengan peningkatan oleh kompetensi pendidik dan tenaga kependidikan yang memadai, serta tidak pula ditunjang oleh manajemen yang baik (Siregar dan Lubis, 2017).

Oleh karena itu konsep mutu harus dipahami sebagai suatu upaya perbaikan dalam membangun mutu. Persoalan mutu merupakan gambaran tentang pandangan hidup (way of life) dan nilai flosofis dalam mengelola masing-masing insitusi yang pada gilirannya hal tersebut bertransformasi menjadi bangunan budaya mutu (Maryono, 2018). Untuk mengantisipasi dan memberikan respon terhadap perubahan tersebut diperlukan suatu bentuk managemen modern yang disebut Manajemen Mutu Terpadu (Total Quality Management).

Gaspersz menyatakan total quality management (TQM) adalah suatu cara meningkatkan kinerja (performance) secara berkelanjutan (continuous performance improvement) pada setiap level operasi dan proses, dalam setiap fungsional dari suatu organisasi dengan menggunakan semua sumber daya manusia dan modal yang tersedia (Gaspersz, 2003). Manajemen mutu terpadu sebagai suatu filosofi dari perbaikan terus menerus, yang dapat memberikan kepada institusi pendidikan seperangkat peralatan untuk memenuhi dan melebihi keinginan, kebutuhan dan harapan pelanggan hari ini dan masa yang akan datang (Sallis, 1996).

Kepala sekolah memiliki peran penting dalam pelaksanaan TQM karena sangat erat kaitannya dengan perubahan budaya, organisasi atas bawah, keterbukaan pada konsumen, kualitas belajar menentukan hambatan dan cara mengatasinya dan strategi perencanaan. Ada dua hal penting, pertama kebutuhan staf di dalam dan di luar lingkungan kerja, dan kedua, sikap kerja yang didukung oleh latar belakang pendidikan dan lingkungan budaya untuk mencapai keberhasilan kerja. Penyusunan personil dan tata kerja organisasi, informasi akurat kepada konsumen, kecakapan memahami permasalahan dan cara mengatasinya serta dinamika dalam perencanaan kesemuanya itu erat kaitannya dengan perbaikan kualitas manajemen.Penerapan manajemen mutu madrasah tentunya kepala sekolah memiliki peran yang kuat dalam mengkoordinasikan, menggerakkan dan menyelaraskan semua sumber daya pendidikan yang tersedia (El Widdah \& Huda, 2018).

Kepala sekolah/madrasah dapat memfokuskan pada pengembangan potensi-potensi yang dimiliki oleh stakeholder internal dan eksternal. Kepala sekolah dengan visi dan misi yang jelas, mampu menjabarkannya dalam bentuk langkah-langkah dan tindakan yang nyata, mampu menggerakkan orang lain untuk bersama-sama bekerja mencapai sekolah bermutu, mampu menggerakkan semua unit-unit misalnya bidang pengajaran dan kurikulum, bidang sarana prasarana dan kesiswaan, serta bidang hubungan masyarakat dan publikasi, serta bidang perencanaan dan keuangan. Sementara unit-unit terkecil lainnya juga mampu digerakkan. Semua bangga menghasilkan dan mengembangkan karya menjadi tidak saja secara meningkat secara kuantitas tetapi juga secara kualitas lebih baik (Kholis, dkk, 2014).

Kepala madrasah dalam hal ini berperan menjalankan kegiatan administrasi pendidikan yaitu suatu proses keseluruhan, kegiatan bersama dalam bidang pendidikan yang meliputi perencanaan, pengorganisasian, pengarahan, pengkoordinasian, pengawasan, pembiayaan, dan pelaporan dengan menggunakan atau memanfaatkan fasilitas yang tersedia, baik personel, material, maupun spiritual untuk mencapai tujuan pendidikan secara efektif dan efsien. Ruang lingkup administrasi pendidikan di sekolah/madrasah ada tujuh kelompok, yaitu: (1) tata laksana sekolah, (2) administrasi guru dan pegawai sekolah, (3) administrasi murid/siswa, (4) administrasi supervisi pengajaran, (5) administrasi pelaksanaan dan pembinaan kurikulum, (6) administrasi perencanaan dan pendirian bangunan sekolah, (7) administrasi hubungan sekolah dan masyarakat (Ramayulis, 2012).

Penyelenggaraan kegiatan administrasi di sekolah bertujuan agar program pendidikan terlaksana secara baik dan memberikan pelayanan yang memuaskan bagi stakeholder pendidikan. Pelaksanaan kegiatan administrasi pendidikan di sekolah dilakukan oleh seorang kepala sekolah yang dibantu oleh tenaga administrasi sekolah. Tenaga administrasi sekolah atau sering disebut sebagai petugas tata usaha sekolah memiliki peran penting dalam penyelenggaraan pendidikan agar tujuan pendidikan tercapai dengan baik. Sesuai dengan hadits Rasulullah SAW yang artinya Rasulullah SAW bersabda: "Tuhanku telah menta'dib (mendidik)ku, maka ia sempurnakan ta'dib (pendidikan) $k u$.

Hadits tersebut memberikan arahan terkait upaya yang dilakukan dalam mempersiapkan individu untuk kehidupan yang lebih sempurna dalam etika, 
sistematis dalam berpikir, memiliki ketajaman intuisi, giat dalam berkreasi, memiliki toleransi pada yang lain berkompetensi dalam hal yang baik, mengungkap dengan dan bahasa lisan dan tulisan yang baik dan benar serta memiliki beberapa keterampilan (Ramayulis, 2012).

Kepala madrasah dalam hal ini harus dapat memimpin perubahan tersebut dengan mengajak semua untuk belajar kembali bagaimana mengelola pendidikan. Kepala madrasah harus dapat menjaga agar tetap ada komitmen untuk melakukan perubahan, inovasi dan perbaikan (Rahayu, 2015). Ada banyak pendekatan yang dapat dipakai untuk menjadikan sekolah lebih bermutu yaitu dengan mensinergikan fungsi kepemimpinan yang efektif dengan implementasi sistem penjaminan mutu dengan melibatkan stakholders sekolah sebanyak mungkin (Kholis, dkk., 2014). Upaya meningkatkan mutu pendidikan dapat dilakukan melalui standarisasi manajemen pendidikan yang tentunya membutuhkan kesanggupan semua stakeholder untuk melakukan perubahan (Rahayu, 2015).

Istilah stakeholder pertama kali diperkenalkan oleh Edward Freeman di Standford Research Institute pada tahun 1963 yang mendefinisikan stakeholder sebagai kelompok maupun individu yang dapat memengaruhi atau dipengaruhi oleh proses pencapaian tujuan suatu organisasi. Definisi lain dari stakeholder adalah pemegang atau pemangku kepentingan. orang atau kelompok tertentu yang mempunyai kepentingan apa pun terhadap sebuah obyek. Stakeholder dalam lembaga pendidikan adalah orang-orang atau badan yang berkepentingan langsung atau tidak langsung terhadap kegiatan pendidikan di sekolah. Menjadi pemegang dan sekaligus pemberi support terhadap pendidikan atau lembaga pendidikan. Lembaga pendidikan memiliki berbagai macam stakeholder.yaitu stakeholder pimer (pemerintah), stakeholder sekunder (kepala sekolah, pendidik dan tenaga kependidikan, siswa, staf administrasi, yayasan dan komite sekolah), dan stakeholder tersier (masyarakat mitra penyedia lapangan pekerjaan atau masyarakat pengguna lulusan lembaga pendidikan) (Muhaimin, dkk., 2010).

Pengelolaan stakeholder di sebuah madrasah adalah upaya untuk melibatkan semua orang atau kelompok yang sinergis dan harmonis antar civitas akademik madrasah dalam upaya mencapai peningkatan mutu madrasah, baik keterlibatan jajaran pemimpin madrasah, tenaga pendidik, tenaga kependidikan, peserta didik, komite, maupun lainnya. Pelibatan atau partisipasi stakeholder tersebut dimaksudkan untuk mengembangkan madrasah yang bermutu (Kholis, dkk, 2014). Tata kelola administrasi yang baik dan akuntabel merupakan salah satu necessary conditions dan pilar penting bagi upaya peningkatan mutu pendidikan madrasah (Kemenag, 2012).

Studi tentang tata kelola stakeholder sekolah belum banyak dilakukan, namun ada beberapa peneliti yang mengkaitkan konsep mutu dengan pengelolaan stakeholder sekolah. Kholis, dkk (2014) dalam penelitiannya menyimpulkan: kepala sekolah merupakan aktor pengembangan budaya sekolah bermutu dan partisipasi stakeholder. Dua aspek mutu yang dicapai bidang akademik dan nonakademik; tingkat partisipasi mulai dari pimpinan, staf pendidik, staf kependidikan, peserta didik, komite sekolah, dan paguyuban kelas. Budaya mutu yang dikembangkan adalah konsolidasi dan mensinergikan potensi internal-eksternal, mendekatkan sekolah dengan masyarakat, bekerjasama dengan berbagai pihak, restrukturisasi dan revitalisasi komite sekolah, dan mengembangkan budaya bersih, indah dan nyaman.

Latifah (2016) menyimpulkan pengelolaan madrasah dalam persfektif Total Quality Management di madrasah sudah berjalan dengan baik. Dilihat dari pengelolaan akademik dan administrasi madrasah yang lebih unggul. Strategi manajemen yang dilaksanakan adalah dengan perencanaan, tindakan, pengorganisasian sumber daya manusia, pemeriksaan hasil, dan memberikan arahan untuk memajukan madrasah yang semakin unggul dengan lulusan yang berkompeten.

Siregar dan Lubis (2017) Kualitas output pendidikan berupa Sumber Daya Manusia (SDM) yang tinggi dan unggul serta dengan ketrampilan yang uptodate hanya dapat dihasilkan dari para pendidikan yang berkualitas. Pendidikan yang baik akan sangat ditentukan bagaimana tenaga pendidikan yang baik juga. Patsun (2015) pengelolaan pendidikan yang baik hendaknya meletakkan transparansi dan akuntabilitas dalam pelaksanaan administrasi kurikulum dan pembelajaran, kesiswaan, pendidik dan tenaga kependidikan, sarana dan prasarana pendidikan, keuangan atau pembiayaan, program hubungan sekolah dengan masyarakat, program bimbingan dan konseling, dan administrasi persuratan yang harus selalu diperhatikan oleh kepala sekolah. 


\section{Jurnal Ilmiah Ekonomi Islam, 7(01), 2021, 260}

Hikmah dan Yudiawan (2019) dalam rangka menciptakan sekolah yang memiliki tata kelola, akuntabilitas, dan citra madrasah yang ideal dapat dilakukan dengan beberapa hal, yakni; (1) Otonomisasi dan Desentralisasi, (2) Manajemen Berbasis Sekolah (3) Manajemen Berbasis Masyarakat. Selanjutnya, citra publik juga berperan penting dalam peningkatan mutu pendidikan. Hal yang dapat dilakukan dalam peningkatan citra publik untuk mendapat kepercayaan dari masyarakat adalah sebagai berikut: Pertama, analisis kebutuhan sosial, menyesuaikan dengan kebutuhan perkembangan sosial yang ada dalam masyarakat. Kedua, pendekatan kebutuhan ketenagakerjaan. Ketiga, pelayanan sekolah. Keempat, daya tarik fisik, membenahi gedung sekolah/madrasah yang menghadap kejalan secara artistik dan dengan desain yang baik, sehingga menarik perhatian masyarakat.

Beberapa kajian yang dilakukan tersebut adalah terkait dengan pengelolaan staf pendidik, staf kependidikan, peserta didik, komite sekolah, dan paguyuban kelas (Kholis, dkk, 2014), pengelolaan akademik dan administrasi madrasah (Latifah, 2016), pengelolaan sumber daya manusia (Siregar dan Lubis, 2017), administrasi kurikulum dan pembelajaran, kesiswaan, pendidik dan tenaga kependidikan, sarana dan prasarana pendidikan, keuangan atau pembiayaan, program hubungan sekolah dengan masyarakat, program bimbingan dan konseling, dan administrasi persuratan (Patsun, 2015).

Kajian-kajian tersebut belum ada yang secara komprehensif menggali unsur-unsur stakeholder madrasah baik internal maupun eksternal. Stakeholder madrasah antara lain kepala madrasah, pendidik dan tenaga kependidikan, siswa, staf administrasi, yayasan dan komite serta stakeholder pelengkap masyarakat mitra dan pengguna lulusan lembaga pendidikan.

Perlu adanya kajian terhadap tata kelola stakeholder madrasah, khususnya tenaga pendidik dan kependidikan, siswa, dan masyarakat mitra, karena ketiganya adalah pelanggan utama jasa pendidikan. Sejalan dengan fokus utama penerapan manajemen mutu terpadu yaitu untuk memenuhi kebutuhan dan tuntutan seluruh pelanggan. Siswa adalah pelanggan utama yang secara langsung menerima jasa, pelanggan kedua yaitu orang tua, dan pelanggan ketiga yaitu pemerintah dan masyarakat secara keseluruhan. Guru, staf dan setiap orang yang bekerja di lingkungan madrasah adalah pelanggan internal. Madrasah yang baik adalah madrasah yang mampu menjaga hubungan dengan pelanggannya dan memiliki orientasi pada mutu. Oleh karena itu perlu dilakukan studi lebih lanjut terkait tentang studi tata kelola stakeholder dalam upaya meningkatkan mutu pendidikan menengah di madrasah.

$\begin{array}{lllll}\text { Madrasah Tsanawiyah Negeri (MTs } & \text { N) } & 1\end{array}$ Sukoharjo yang berada di wilayah Desa Cangkol merupakan salah satu Madrasah Tsanawiyah yang memiliki kualitas yang sangat baik sekaligus menjadi rujukan bagi madrasah Tsanawiyah yang lain baik negeri maupun swasta khususnya di wilayah Sukoharjo dan sekitarnya. Kondisi yang demikian inilah perlu dilakukan kajian atau penelitian agar dapat memberikan manfaat yang lebih luas lagi bagi kehidupan masyarakat.

Berdasarkan latar belakang masalah di atas, peneliti tertarik melakukan penelitian dengan mengangkat tema "Tata Kelola Stakeholder dalam Meningkatkan Mutu Pendidikan Pada Madrasah Tsanawiyah" dengan obyek penelitian di MTs Negeri 1 Sukoharjo.

\section{KAJIAN TEORI}

\subsection{Mutu Pendidikan Madrasah}

Mutu didefinisikan sebagai suatu kondisi dinamik yang berhubungan dengan produk atau jasa, manusia, proses dan lingkungan yang memenuhi atau melebihi harapan. Kondisi dinamik di sini diartikan selalu berubah untuk mendekati kesempurnaan sedangkan memenuhi atau melebihi harapan berkaitan dengan kepuasan konsumen atau pengguna jasa (Tjiptono, 1997). Konsep mutu dalam bidang pendidikan merupakan gambaran dan karakteristik menyeluruh yang menunjukkan kemampuan dalam memenuhi kebutuhan yang diharapkan atau yang tersirat, yaitu mulai dari input, proses dan output pendidikan yang dihasilkan (Mulyasa, 2007). Dapat dinyatakan bahwa pendidikan yang bermutu adalah pendidikan yang menimbulkan kesinambungan antara input, proses dan hasil pembelajaran peserta didik.

Mutu pendidikan ditentukan oleh input, proses dan output pendidikan. Oleh sebab itu, mutu pendidikan sekolah/madrasah merupakan kemampuan mengelola input, proses dan mendayagunakan secara optimal untuk meningkatkan kemampuan belajar dan hasil belajar lulusannya (Sallis, 1993). Mutu di bidang pendidikan termasuk mutu input, proses, output, dan outcome. Input pendidikan dinyatakan bermutu jika 


\section{Jurnal Ilmiah Ekonomi Islam, 7(01), 2021, 261}

siap berproses. Proses pendidikan bermutu yang mampu mengintegrasikan iman, ilmu, akhlak dan budaya. Keluaran pendidikan dinyatakan bermutu jika hasil belajar akademik siswa tinggi. Hasil dinyatakan bermutu jika lulusan terserap di dunia kerja, dengan gaji wajar, dan semua pihak menyatakan kehebatan lulusan serta mereka merasa puas (Usman, 2008).

Sebagai suatu jasa layanan, pendidikan harus memiliki karakteristik tertentu yang memenuhi mutu sebuah layanan. Karakteristik-karakteristik mutu untuk pelayanan adalah (1) ketepatan waktu pelayanan, (2) akurasi pelayanan, (3) kesopanan dan keramahan dalam memberikan pelayanan, (4) tanggungjawab terhadap mutu jasa/produk serta menangani keluhan pelanggan, (5) kelengkapan pelayanan yaitu ketersediaan sarana dan pelayanan: inovasi pelayanan, penyesuaian dengan kebutuhan/selera pelanggan, (6) pelayanan pribadi, (7) kenyamanan dalam memperoleh pelayanan: berhubungan dengan lokasi/ruangan tempat pelayanan, fasilitas, ketersediaan informasi petunjukpetunjuk lain dan (8) atribut pendukung kenyamanan pelayanan seperti lingkungan kondusif, bersih dan ruangan nyaman dan lain-lain. Hal ini sangat identik dan tepat untuk diadopsi dan diaplikasikan dengan karaktersitik mutu layanan pendidikan. Yang dimaksud dengan layanan pendidikan yaitu layanan-layanan kurikuler, administrasi, ekstrakurikuler, kebijakan umum, serta bagi pendidikan tinggi termasuk jasa pengabdian pada masyarakat (El Widdah \& Huda, 2018).

Selama ini yang menjadi indikator variabel mutu pendidikan adalah meliputi (1) rata-rata NEM siswa baru kelas satu dan lulusan, (2) angka mengulang/tinggal kelas, putus sekolah (drop out) dan angka lulusan, (3) kualifikasi guru yang layak mengajar, (4) jumlah guru menurut lulusan dan bidang studi yang diajarkan, (5) aktivitas guru dalam kegiatan MGMP, (6) kondisi ruang kelas, (7) persentase sekolah yang memiliki perpustakaan dan lapangan olahraga, UKS, laboratorium, ruang keterampilan, ruang konseling, dan ruang serba guna, (8) frekuensi pendayagunaan sarana perminggu, (9) partisipasi orangtua, dan (10) biaya pendidikan. Dari sepuluh indikator variabel mutu tersebut, kesemuanya telah mencakup input, process dan output (El Widdah \& Huda, 2018).

Indikator-indikator mutu tersebut $\mathrm{di}$ atas cenderung menekankan pada pendekatan input, proses dan ouput yang merupakan indikator mutu.
Pendekatan ini merupakan suatu pendekatan sistem, yang dalam dunia pendidikan merupakan suatu kesatuan sistem yang saling mempengaruhi terutama untuk mendapatkan ouput yang bermutu, diperlukan suatu input dan proses yang bermutu pula.

\subsection{Manajemen Mutu Terpadu dalam Pendidikan}

Manajemen mutu merupakan semua aktivitas dari fungsi manajemen secara keseluruhan yang menentukan kebijaksanaan mutu, tujuan dan tanggung jawab, serta mengimplementasi-kannya melalui alatalat manajemen mutu (Gaspersz, 2003). Manajemen mutu merupakan tindakan mengawasai semua kegiatan dan tugas-tugas yang diperlukan untuk mempertahankan tingkat keunggulan yang diinginkan. Manajemen mutu termasuk penentuan kebijakan mutu, menciptakan dan menerapkan perencanaan mutu dan jaminan dan kontrol kualitas dan peningkatan mutu.

Konsep manajemen mutu terus mengalami perkembangan yang dimulai dari mutu inspeksi (inspection quality), pengendalian mutu (quality control), penjaminan mutu (quality assurance), hingga sampai dengan manajemen mutu terpadu (total quality management). Total Quality Management (TQM) merupakan proses untuk mengelola mutu; sebuah filosofi yang menekankan pada perbaikan dalam segala hal, yang terdiri atas sejumlah prinsip dan merupakan fondasi untuk melakukan perbaikan berkelanjutan (Goetsch \& Davis, 2006).

Penerapan manajemen kualitas pada lembaga pendidikan modern sekarang mulai mengadopsi Total Quality Management (TQM), yaitu sebuah filosofi tentang perbaikan secara terus-menerus yang dapat memberikan seperangkat alat praktis kepada setiap institusi pendidikan dalam menambahi kebutuhan, keinginan, dan harapan para pelanggannya saat ini dan masa yang akan datang (Sallis, 1993).

Manajemen Mutu Terpadu adalah pendekatan strategis yang praktis untuk menjalankan organisasi dan difokuskan pada kepentingan konsumen atau klien. Perbaikan Manajemen Mutu Terpadu misalnya inovasi yang konstan, perubahan program, penekanan pada program tertentu, kualitas manager, tanggungjawab, kebebasan berkreasi dalam kerangka kerja serta kejelasan tujuan. Dalam bahasa Jepang kata untuk perbaikan berkesinambungan disebut kaizen. Esensi kaizen yang merupakan proyek kecil untuk meningkatkan 
keberhasilan dan keyakinan diri, untuk selanjutnya dapat memperbaiki dan meningkatkan kualitas manajemen. Pendekatan perbaikan kualitas tidak diartikan implementasi kepentingan dengan biaya yang mahal, tetapi upaya yang sungguh-sungguh untuk memperbaiki segala kekurangan (El Widdah \& Huda, 2018).

\subsection{Stakeholder Pendidikan}

Stakeholder dalam lembaga pendidikan adalah orang-orang atau badan yang berkepentingan langsung atau tidak langsung terhadap kegiatan pendidikan di sekolah. Menjadi pemegang dan sekaligus pemberi support terhadap pendidikan atau lembaga pendidikan (Muhaimin, dkk., 2010). Merujuk pada UU Sistem Pendidikan Nasional No. 20 tahun 2003, khususnya Pasal 56 menjelaskan bahwa stakeholder, yaitu:

a. Masyarakat berperan dalam peningkatan mutu pelayanan pendidikan yang meliputi perencanaan, pengawasan dan evaluasi program pendidikan melalui dewan pendidikan dan komite sekolah.

b. Dewan pendidikan sebagai lembaga mandiri dibentuk dan berperan dalam peningkatan mutu pelayanan pendidikan tenaga sarana dan prasarana, serta pengawasan pendidikan pada tingkat nasional, provinsi, dan kabupaten/ kota yang tidak mempunya hubungan hierarkis.

c. Komite sekolah sebagai lembaga mandiri, dibentuk dan berperan dalam peningkatan mutu pelayanan dengan memberikan pertimbangan, arahan dan dukungan tenaga, sarana dan prasarana, serta pengawasan pendidikan pada tingkatan satuan pendidikan.

Muhaimin, dkk (2010) membagi menjadi stakeholder primer, sekunder, dan tersier.

a. Stakeholder pimer (utama) adalah stakeholder yang memiliki keterlibatan secara langsung dengan suatu kebijakan pendidikan, penentu utama dalam proses pengambilan keputusan, yaitu pemerintah.

b. Stakeholder sekunder (Pendukung), adalah stakeholder yang memiliki keterkaitan langsung dalam pendidikan dan menjadi pelaku dalam mengimplementasikan kebijakan dari stakeholder primer. Yang dimaksud dalam pembagian stakeholder ini adalah kepala sekolah, pendidik dan tenaga kependidikan, siswa, staf administrasi, yayasan dan komite sekolah. c. Stakeholder tersier (pelengkap), merupakan stakeholder yang tidak memiliki pengaruh dalam kebijakan pendidikan dan pelaksanaan atau implementasi kebijakan pendidikan, namun memiliki hak untuk menentukan penilaian terhadap kebijakan pendidikan dan memiliki hak untuk menggunakan lulusan lembaga pendidikan. Stakeholder ini adalah masyarakat mitra penyedia lapangan pekerjaan atau masyarakat pengguna lulusan lembaga pendidikan.

Peran setiap stakeholder dalam pendidikan memiliki peran yang berbeda-beda, mulai dari penentuan kebijakan pendidikan, implementasi kebijakan dan pengguna lulusan (Mulyasa, 2007).

a. Pemerintah, berperan mengusahakan dan menyelanggarakan sistem pendidikan nasional yang meningkatkan keimanan dan ketakwaan serta akhlak mulia dalam rangka mencerdaskan kehidupan bangsa.

b. Kepala sekolah, berperan dalam mengatur rumah tangga sekolah, memelihara hubungan baik sekolah dengan orang tua, lembaga-lembaga lain baik pemerintah maupun swasta

c. Guru, berperan dalam pembelajaran anak dan komunikasi secara berkala dengan: orang tua atau wali tentang kemajuan anak dalam belajar

d. Orang tua, berperan untuk mendukung pelaksanaan belajar mengajar di sekolah, berpartisipasi aktif dalam kegiatan belajar di rumah,

e. Komite sekolah, berperan sebagai pemberi pertimbangan dalam penentuan dan pelaksanan kebijakan pendidikan di sekolah

f. Masyarakat usaha, berperan dalam mendukung kebijakan sekolah, tidak hanya sekedar memeras dan menjadikan lulusan sekolah sebagai obyek komoditas.

\section{METODOLOGI PENELITIAN}

Penelitian ini menggunakan pendekatan kualitatif dengan alasan penelitian kualitatif lebih fleksibel, dapat menggali data secara mendalam dan digunakan untuk meneliti kehidupan masyarakat, tingkah laku atau hubungan kekerabatan (Mack,et, al., 2005). Selain itu, permasalahan yang dikaji adalah makna dari suatu tindakan atau apa yang berada dibalik tindakan seseorang. Penelitian kualitatif memberikan peluang untuk melakukan pengkajian mendalam terhadap suatu fenomena. Penelitian kualitatif memungkinkan untuk digunakan dalam 
penelitian tentang keyakinan, kesadaran dan tindakan individu di dalam masyarakat, karena yang dikaji ialah fenomena yang tidak bersifat eksternal dan berada di dalam diri masing-masing individu. Penelitian kualitatif memungkinkan untuk meneliti fenomena secara holistik. Fenomena yang dikaji merupakan suatu kesatuan yang tak terpisahkan karena tindakan tidak hanya diakibatkan oleh satu atau dua faktor saja, akan tetapi melibatkan sekian banyak faktor yang saling terkait satu sama lain. Penelitian kualitatif memberikan kesempatan untuk memahami fenomena berdasarkan pandangan aktor setempat (Mack,et,al, 2005).

Penelitian dilaksanakan di Madrasah Tsanawiyah Negeri (MTs N) 1 Sukoharjo yang berada di wilayah Desa Cangkol. Pemilihan madrasah ini sebagai tempat penelitian dikarenakan MTs Negeri 1 Sukoharjo merupakan salah satu Madrasah Tsanawiyah yang memiliki kualitas yang sangat baik sekaligus menjadi rujukan bagi madrasah Tsanawiyah yang lain baik negeri maupun swasta. Teknik pengumpulan data pada penelitian ini antara lain observasi, wawancara mendalam (indepthinterview), FGD (Focus Group Discussion), dan telaah dokumen (Mack, et, al., 2005). Analisis data dalam penelitian ini dilakukan dengan 4 (empat) langkah yaitu: 1) melakukan manajemen data, 2) menulis memo di tepi catatan lapangan atau transkrip untuk membantu eksplorasi database, 3) penggambaran, penggolongan, dan interpretasi, dan 4) visualisasi dan representasi temuan. Keempatproses tersebut merupakan siklus, dimana proses pengumpulan data, reduksi data, penyajian data dan penarikan kesimpulan.

\section{HASIL PENELITIAN}

4.1. Tata kelola tenaga pendidik dan tenaga kependidikan dalam meningkatkan mutu pendidikan menengah pada Madrasah Tsanawiyah (MTs) Negeri 1 Sukoharjo.

Tata kelola tenaga pendidik serta tenaga kependidikan yang ada di Madrasah Tsanawiyah (MTs) Negeri 1 Sukoharjo meliputi: melakukan analisis pekerjaan dan kelemahan para peserta didik yang ada di MTs Negeri 1 Sukoharjo, melakukan rekrutmen tenaga pendidik dan tenaga kependidikan yang dilakukan dengan cara memilih yang sesuai dalam bidang yang diperlukan secara profesional (obyektif) serta mempunyai tingkat kemampuan berkomunikasi minimal baik atau bahkan sangat baik. Pembinaan yang dilakukukan di Madrasah
Tsanawiyah (MTs) Negeri 1 Sukoharjo ini berbedabeda serta beragam, kalau tenaga pendidik pembinaan yang dilakukan dengan mengundang narasumber dari luar untuk melakukan kegiatan diskusi dalam meningkatkan kualitas para tenaga pendidik, sedangkan untuk tenaga kependidikan pembinaannya diselenggarakan oleh pihak Madrasah Tsanawiyah (MTs) Negeri 1 Sukoharjo maupun oleh Kementerian Agama Sukoharjo, dan untuk kasus pemberhentian terhadap tenaga pendidik dan tenaga kependidikan alhamdulillah belum pernah terjadi atau dilakukan kecuali pemberhentian tersebut dikarenakan tenaga pendidik serta tenaga kependidikan meninggal dunia.

Penilian terhadap tenaga pendidik di Madrasah Tsanawiyah (MTs) Negeri 1 Sukoharjo dilakukan oleh kepala sekolah dengan melihat hasil raport para peserta didik serta melihat daftar hadir tenaga pendidik melalui fingerprint, kemudian untuk penilaian tenaga kependidikan kepala Madrasah Tsanawiyah (MTs) Negeri 1 Sukoharjo melihat daftar hadir tenaga pendidik melalui fingerprint, melihat catatan harian mereka dan melihat kinerja para tenaga kependidikan secara obyektif yang terpantau setiap harinya.

4.2. Tata kelola siswa dalam meningkatkan mutu pendidikan pada Madrasah Tsanawiyah (MTs) Negeri 1 Sukoharjo.

Tata kelola siswa dalam meningkatkan mutu pendidikan pada Madrasah Tsanawiyah Negeri 1 Sukoharjo pertama kali dilakukan dengan peningkatan profesionalisme guru sebagai ujung tombak pelaksanaan kurikulum, sebab hal itu (profesionalisme guru) merupakan faktor yang tidak kalah pentingnya dengan kurikulum itu sendiri. Seorang guru yang profesional akan mampu mengembangkan silabus, metode, dan materi pembelajaran walau hanya dengan kurikulum yang sederhana terlebih dengan kurikulum yang baik. Selain itu, metode penyampaian pembelajaran yang aktif dan kreatif dilakukan oleh para tenaga pengajar/pendidik di Madrasah Tsanawiyah Negeri 1 Sukoharjo yang pada akirnya siswa mampu meningkatkan prestasinya (mutunya) dalam melaksanakan kegiatan pembelajaran yang ada di Madrasah Tsanawiyah Negeri 1 Sukoharjo. Salah satu metode yang sering digunakan dalam meningkatkan mutu pendidikan melalui tata kelola siswa pada Madrasah Tsanawiyah Negeri 1 Sukoharjo yaitu metode Snowball Throwing. 
Pada pembelajaran Snowball Throwing, guru berusaha memberikan kesempatan secara luas kepada para siswanya untuk mengembangkan keterampilan menyimpulkan isi berita atau informasi yang mereka peroleh dalam konteks nyata dan situasi yang kompleks. Guru juga memberikan pengalaman kepada siswa melalui pembelajaran terpadu dengan menggunakan proses yang saling berkaitan dalam situasi dan konteks komunikasi alamiah baik sosial, sains, hitungan dan lingkungan pergaulan. Dibentuk kelompok yang diwakili ketua kelompok untuk mendapat tugas dari guru kemudian masing-masing siswa membuat pertanyaan yang dibentuk seperti bola (kertas pertanyaan) lalu dilempar ke siswa lain yang masing-masing siswa menjawab pertanyaan dari bola yang diperoleh. Di samping berbagai metode lain yang sifatnya merangsang kreatifitas siswa atau peserta didik terus dilakukan dengan tujuan mutu pendidikan di Madrasah Tsanawiyah Negeri 1 Sukoharjo semakin meningkat dari waktu ke waktu yang menghasilkan peserta didik yang berprestasi baik IPTEK maupun keilmuan keagamaannya sehingga keseimbangan terhadap keilmuan keduanya diperoleh peserta didik.

\subsection{Madrasah mengelola peran serta stakeholder} dalam meningkatkan mutu pendidikan menengah pada Madrasah Tsanawiyah (MTs) Negeri 1 Sukoharjo.

Berdasarkan berbagai temuan data yang ada di lapangan yang telah disajikan, dianalisis, dan diinterpretasikan sebelumnya, partisipasi stakeholder di lingkungan Madrasah Tsanawiyah (MTs) Negeri 1 Sukoharjo terlaksana dengan didukung oleh partisipasi stakeholder dalam perencanaan, partisipasi stakeholder dalam implementasi, partisipasi stakeholder dalam evaluasi, partisipasi stakeholder dalam manfaat program. Partisipasi stakeholder dalam perencanaan program di Madrasah Tsanawiyah (MTs) Negeri 1 Sukoharjo dapat terlaksana dengan baik karena terdapat peranan yang dilakukan oleh kepala sekolah, komite, guru, dan tenaga kependidikan dalam perencanaan pelaksanaan program-program Madrasah Tsanawiyah (MTs) Negeri 1 Sukoharjo. Partisipasi stakeholder dalam implementasi terlaksana, karena seluruh stakeholder terlibat dalam pelaksanaan program, mulai dari pihak internal yang meliputi kepala sekolah, komite, guru, murid, staff TU, pengelola kantin, petugas kebersihan, dan penjaga sekolah yang memiliki peranan masing-masing. Pihak eksternal meliputi perwakilan dari Dinas Pendidikan
Kabupaten Sukoharjo, perwakilan Dinas Kebersihan dan Pertamanan Kabupaten Sukoharjo, dan Badan Lingkungan Hidup Kabupaten Sukoharjo. Partisipasi stakeholder dalam melakukan evaluasi terlaksana karena dalam mengatasi masalah pelaksanaan program, stakeholder dapat memberi solusi. Partisipasi stakeholder dalam memperoleh manfaat program cukup banyak, terdapat hubungan dengan pembangunan berkelanjutan yang bermanfaat bagi setiap stakeholder yang berpartisipasi dalam program. Keseluruhan program yang terlaksana di Madrasah Tsanawiyah (MTs) Negeri 1 Sukoharjo telah berjalan dan sesuai dengan program yang telah direncanakan.

\section{KESIMPULAN}

Berdasarkan hasil penelitian, maka dapat disimpulkan bahwa tata kelola stakeholder dalam meningkatkan mutu pendidikan pada Madrasah Tsanawiyah (MTs) Negeri 1 Sukoharjo yang meliputi tata kelola tenaga pendidik dan tenaga kependidikan, tata kelola siswa, dan bagaimana madrasah mengelola peran serta stakeholder dalam meningkatkan mutu pendidikan menengah pada Madrasah Tsanawiyah (MTs) Negeri 1 Sukoharjo dilakukan dengan sangat baik sekali sehingga mutu pendidikan pada Madrasah Tsanawiyah (MTs) Negeri 1 Sukoharjo sangat baik.

\section{REFERENCES}

El Widdah, M. \& Huda, S. (2018). Manajemen Strategi Peningkatan Mutu Madrasah. Jambi: Salim Media Indonesia

Gaspersz, V. (2003). Sistem Manajemen Kinerja Terintegrasi: Balanced Scorecard dengan Six Sigma Untuk Organisasi Bisnis dan Pemerintah. Jakarta: Gramedia Pustaka Utama. Goetsch, D.L., \& Davis, S.B. (2006). Quality Management: Introduction to Total Quality Management for Production, Processing and Service. New Jersey: Prentice-Hall, Inc.

Hikmah, A. N., \& Yudiawan, A. (2019). Manajemen dan Kebijakan Madrasah melalui Penguatan Tata Kelola, Akuntabilitas dan Citra Publik Pendidikan. Jurnal Pendidikan Islam: ALFIKR Vol.5, No.1, Juni 2019 ISSN 2088-690X

Kemenag. (2012). Standar Dokumen Administrasi Madrasah. Jakarta: Unit Pelaksana Program Akreditasi Madrasah (UPPAM), Direktorat Pendidikan Madrasah, Ditjen Pendidikan Islam, Kementerian Agama RI. 
Jurnal Ilmiah Ekonomi Islam, 7(01), 2021, 265

Kholis, N; Zamroni, \& Sumarno. (2014). Mutu Sekolah Dan Budaya Partisipasi Stakeholders: Studi Fenomenologi di Sekolah Konfesional MIN Tegalasari Wlingi Blitar. Jurnal Pembangunan Pendidikan: Fondasi dan Aplikasi Volume 2, Nomor 2, 2014.

Latifah, I N. (2016). Pengelolaan Madrasah Dalam Persfektif Total Quality Management Di Min Hadiluwih Sumberlawang Sragen Tahun Ajaran 2015/2016. Jurusan Manajemen Pendidikan Islam Program Pascasarjana Institut Agama Islam Negeri Surakarta

Mack, N., Woodsong, C., MacQueen, K.M., Guest, G., \& Namey, E. (2005). Qualitative Research Methods: A Data Collector's field Guide. North Carolina: Family Health International \&Usaid.

Maryono. (2018). Akuntabilitas Sekolah; Suatu Upaya Meningkatkan Mutu Pendidikan Madrasah. Jurnal Paramurobi, Vol. 1, No. 1, Januari-Juni 2018.

Muhaimin, dkk, (2010). Manajemen Pendidikan, Aplikasinya dalam Penyusunan Pengembangan Sekolah/Madrasah. Jakarta: Prenada Media Group.

Mulyasa, E. (2007). Manajemen Berbasis Sekolah, Konsep Strategi dan Implementasi. Bandung: Remaja Rosda Karya
Patsun. (2015). Paradigma Administrasi Dalam Pengelolaan Sekolah. Jurnal Cendekia: Jurnal Studi Keislaman Volume 1, Nomor 2, Desember 2015: ISSN 2443-2741

Rahayu, M. (2015). Pelaksanaan Standar Pengelolaan Pendidikan di Sekolah Dasar. Jurnal PenelitianIlmu Pendidikan Volume 8, Nomor 1, Maret 2015

Ramayulis. 2012. Manajemen Pendidikan Islam. Malang: Erlangga.

Sallis, E. (1996). Total Quality Management in Education. London: Philadelphia Kogan PageLimited.

Siregar, A. N. \& Lubis, W. (2017). Manajemen Pendidik Dan Tenaga Kependidikan Dalam Meningkatkan Mutu Pendidikan. Jurnal Educandu Volume: X Nomor: 1 Edisi: Juni 2017 Sukmadinata, N. S. ; Jami'at, Ayi N; \& Ahman. (2006). Pengendalian Mutu Pendidikan Sekolah Menengah: Konsep, Prinsip dan Instrumen. Bandung: Refika Aditam.

Tjiptono, F. 1997. Prinsip-prinsip Total Quality Service. Yogyakarta: Andi Offset.

Usman, H. 2008. Manajemen : Teori, Praktek dan Riset Pendidikan. Jakarta: Bumi Aksara 